\title{
Paragrandidierella minima, a New Genus and Species of Aoridae (Crustacea: Amphipoda) from Osaka Bay, Central Japan
}

\author{
Hiroyuki Ariyama \\ Osaka Prefectural Fisheries Experimental Station, Tanagawa, \\ Misaki, Osaka, 599-0311 Japan \\ E-mail:ariyama@deneb.freemail.ne.jp
}

(Received 18 July 2001; Accepted 31 January 2002)

\begin{abstract}
The monotypic genus Paragrandidierella (Crustacea: Amphipoda: Aoridae) is erected with $P$. minima sp. nov. from Osaka Bay, central Japan, as its type species. Paragrandidierella closely resembles Chevreuxius Bonnier, 1896, Grandidierella Coutière, 1904, and Orstomia Myers, 1998 in having a carpochelate male gnathopod 1 and uniramous uropod 3; however, it can be distinguished readily by the non-spinose inner plate of the maxilliped, the reduced uropods, and the short telson with a pair of dorsal swellings.

Key Words: Paragrandidierella, new genus, new species, Aoridae, Amphipoda, Crustacea, Osaka Bay.
\end{abstract}

\section{Introduction}

In 1988 Dr. H. Yokoyama of the National Research Institute of Aquaculture sent me for identification several samples of amphipods collected from Osaka Bay. In these samples I found five small specimens that I provisionally identified as Grandidierella sp. Afterwards, I described four species of Grandidierella from Osaka Bay (Ariyama 1996), but the mentioned specimens did not match any of them. Recently, closer examination has revealed that they belong to an undescribed species, which in turn calls for the erection of a new genus in the Aoridae. In this paper, the new monotypic genus Paragrandidierella is proposed, with this new species, named $P$. minima, as its type species. The new genus is compared with Chevreuxius Bonnier, 1896, Grandidierella Coutière, 1904, and Orstomia Myers, 1998. The body length was measured from the apex of the rostrum along the dorsal margin to the distal end of the telson. The type materials are deposited in the Osaka Museum of Natural History (OMNH).

\section{Systematics}

Paragrandidierella gen. nov.

[Japanese name: hime-dorosokoebi-zoku, new]

Diagnosis. Body subcylindrical, smooth; urosomites free, shortened. Rostrum 
indistinct. Antenna 2 with peduncle stout; flagellum short. Upper lip entire. Mandibular palp slender; articles 2 and 3 subequal, longer than article 1. Mandibular process of lower lip long. Inner plate of maxilla 1 without setae; outer plate with distal thick spines and setae; palp 2-articulated and lacking distal spines. Inner plate of maxilliped without distal spines; outer plate broad, exceeding apex of palp article 2, with several marginal spines; palp consisting of 4 articles, its article 2 long and article 4 with 1 claw. Coxae 1-7 small, almost disjunct. Male gnathopod 1 greatly enlarged, carpochelate; article 5 broad, its posterodistal corner with long tooth; article 6 smaller than article 5. Female gnathopod 1 smaller than that of male, simple; article 5 longer than article 6 . Gnathopods 2 of both sexes smaller than gnathopods 1 , subchelate; article 5 of each gnathopod longer than article 6 . Pereopods 3 and 4 slender; pereopod 6 long; pereopod 7 extremely long. Pleopods short; uropods reduced. Uropod 1 biramous, stout; peduncle shorter than either ramus, with long inter-ramal process; both rami spinose. Uropod 2 biramous, short; inter-ramal process absent; tips of both rami with a few spines. Uropod 3 uniramous, small, with several long setae terminally. Telson short, entire, with pair of dorsal swellings.

Type species. Paragrandidierella minima, sp. nov. (monotypy).

Remarks. The short telson with dorsal swellings of this new genus is a unique character in Aoridae. Paragrandidierella closely resembles Chevreuxius, Grandidierella, and Orstomia in having a carpochelate male gnathopod 1 and uniramous uropod 3; however, the new genus can be distinguished readily by the non-spinose inner plate of the maxilliped, the reduced uropods, and the short telson. In addition, the new genus differs from Chevreuxius in the biramous uropod 2 (Myers 1998a), from Grandidierella in the simple female gnathopod 1 (Barnard and Karaman 1991), and from Orstomia in the non-falcate mandibular palp (Myers 1998b).

Paragrandidierella minima sp. nov.

(Figs 1-6)

[Japanese name: hime-dorosokoebi, new]

Material examined. Holotype: male (OMNH-Ar-4922), $2.13 \mathrm{~mm}$ long, sandy bottom off Kamaguchi $\left(34^{\circ} 29^{\prime} \mathrm{N}, 134^{\circ} 58^{\prime} \mathrm{E}\right)$, Awaji Island, Hyogo Prefecture, $3 \mathrm{~m}$ deep, 22 Aug. 1987, coll. M. Tanda and H. Yokoyama. Allotype: female (OMNH-Ar4923), $2.09 \mathrm{~mm}$ long, same data as the holotype. Paratypes: 2 males (OMNH-Ar-4924, 4925), $2.16 \mathrm{~mm}$ and $1.92 \mathrm{~mm}$ long (not dissected), and 1 female (OMNH-Ar-4926), 1.83 $\mathrm{mm}$ long, same data as the holotype.

Description. Male holotype (Figs 1-5). Body (Fig. 1) subcylindrical. Head long; rostrum indistinct; eyes relatively small. Pereon segments each lacking ventral process. Lateral surfaces of pereonites 5-7 produced posteriorly. Urosomite 2 with blunt dorsal keel.

Antenna 1 (Fig. 2A) with peduncular article 1 bearing several setae on lateral surface and spine at ventrodistal corner; peduncular articles 2 and 3 and flagellum lost. Antenna 2 (Fig. 2B) with peduncle stout; inner surface of article 3 with 2 spines; posterodistal corner of article 5 inflated; flagellum short, as long as peduncular article 5, consisting of 5 articles with article 1 longest, article 5 minute, and articles $2-4$ armed with 1,2 , and 2 spines, respectively. 


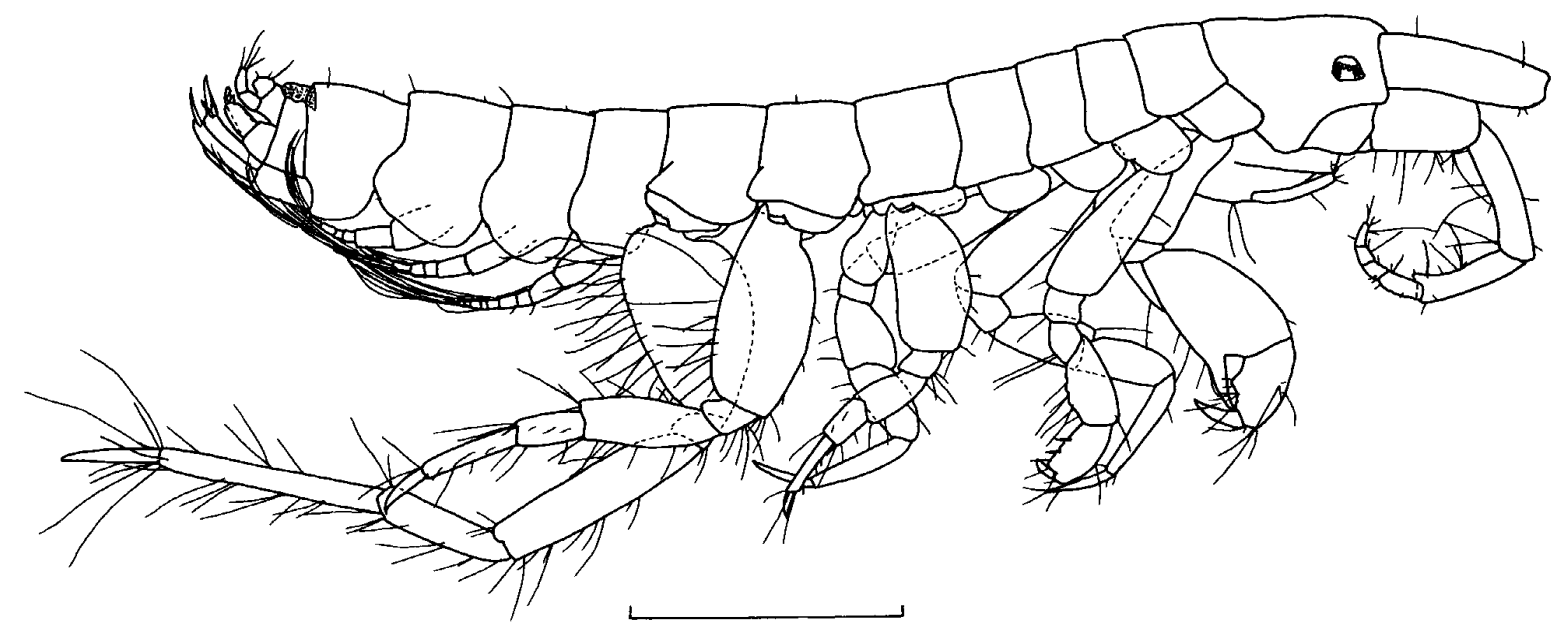

Fig. 1. Paragrandidierella minima, gen. nov., sp. nov., male (holotype, OMNH-Ar-4922). Habitus, right lateral view. Scale: $0.5 \mathrm{~mm}$.

Upper lip (Fig. 2C) with ventral margin almost straight, bearing many thin setae; dorsal and lateral margins each with blunt projection. Left mandible (Fig. 2D) with teeth of incisor small; palp slender, article length ratio $1: 1.9: 1.8$; articles 2 and 3 with 1 and 6 setae, respectively. Right mandible (Fig. 2E) almost similar to left one. Lower lip (Fig. 2F) with mandibular process long; apical margin of inner lobe with minute projection; apical parts of outer and inner lobes covered with thin setae. Maxilla 1 (Fig. 2G) with inner plate roundish-triangular, short, devoid of setae; outer plate pointed apically, with 3 thick spines and 5 setae; palp 2-articulated; tip of palp article 2 with 3 setae. Maxilla 2 (Fig. $2 \mathrm{H}$ ) with inner plate elongatetriangular; medial margin of inner plate with row of setae; apical margin of outer plate truncate, with many setae. Maxilliped (Fig. 2I) with inner plate produced mediodistally, its distal margin bearing many thick setae but lacking distal spines; outer plate broad, slightly notched apically, exceeding apex of palp article 2, with 6 marginal spines and apical thick seta; palp consisting of 4 articles with article 2 long and article 4 short with 1 claw.

Gnathopod 1 (Fig. 3A) greatly enlarged, carpochelate; coxal plate lozengeshaped; article 2 wide, excavate anterodistally, with seta on posterodistal corner; article 3 short; article 4 triangular with a few setae, on posterior surface; article 5 large, broad, its anterior margin rounded and posterodistal corner with long, acute tooth; article 6 narrow, smaller than article 5, expanded at middle part of posterior margin; article 7 claw-like, minutely serrate along inner margin. Gnathopod 2 (Fig. 3B) slender, subchelate; coxal plate roundish-trapezoidal; article 2 elongate, slightly dilated distally; article 4 trapezoidal, with several setae on distal margin; article 5 longish-triangular, with posterior margin setose; article 6 rectangular, about two-thirds as long as article 5, with 2 spines on posterior margin; palm of article 6 transverse, defined by 2 spines (Fig. 3B1); article 7 short, about one-third as long as article 6 , triangular, articulated to middle portion of distal margin of article 6, with tip curved posteriorly.

Pereopods 3 and 4 (Fig. 3C, D) similar to each other; coxal plates roundish-rectangular; articles 2 slender; articles 3 short; articles 4 dilated distally; articles 5 

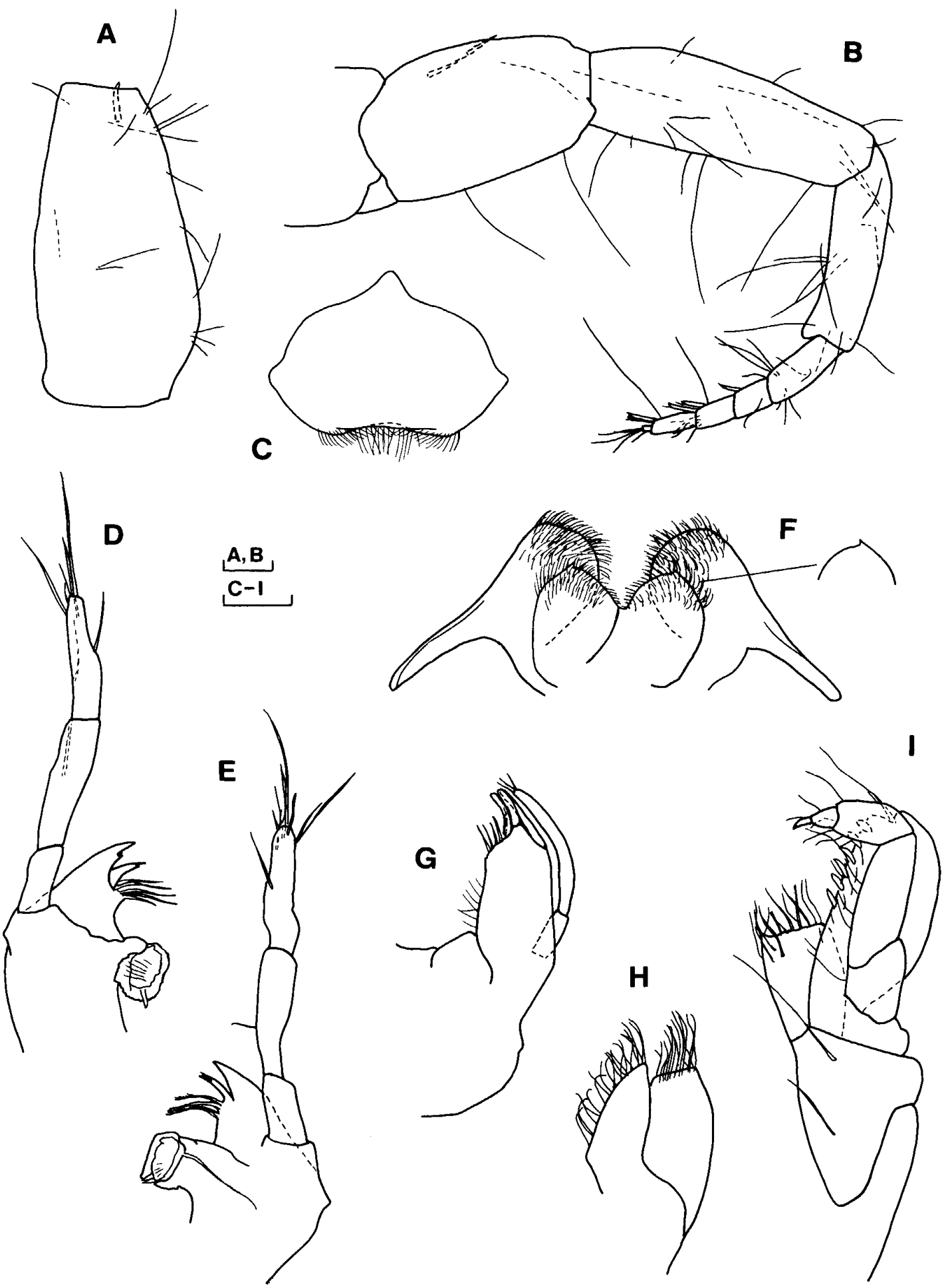

Fig. 2. Paragrandidierella minima, gen. nov., sp. nov., male (holotype, OMNH-Ar-4922). A, right antenna 1 (dorsal view); $\mathrm{B}$, right antenna 2 (lateral view); $\mathrm{C}$, upper lip (anterior view); $\mathrm{D}$, left mandible (internal view); E, right mandible (internal view); F, lower lip (ventral view); $G$, left maxilla 1 (ventral view); $H$, left maxilla 2 (ventral view); I, left maxilliped (ventral view). Scales: $0.05 \mathrm{~mm}$. 


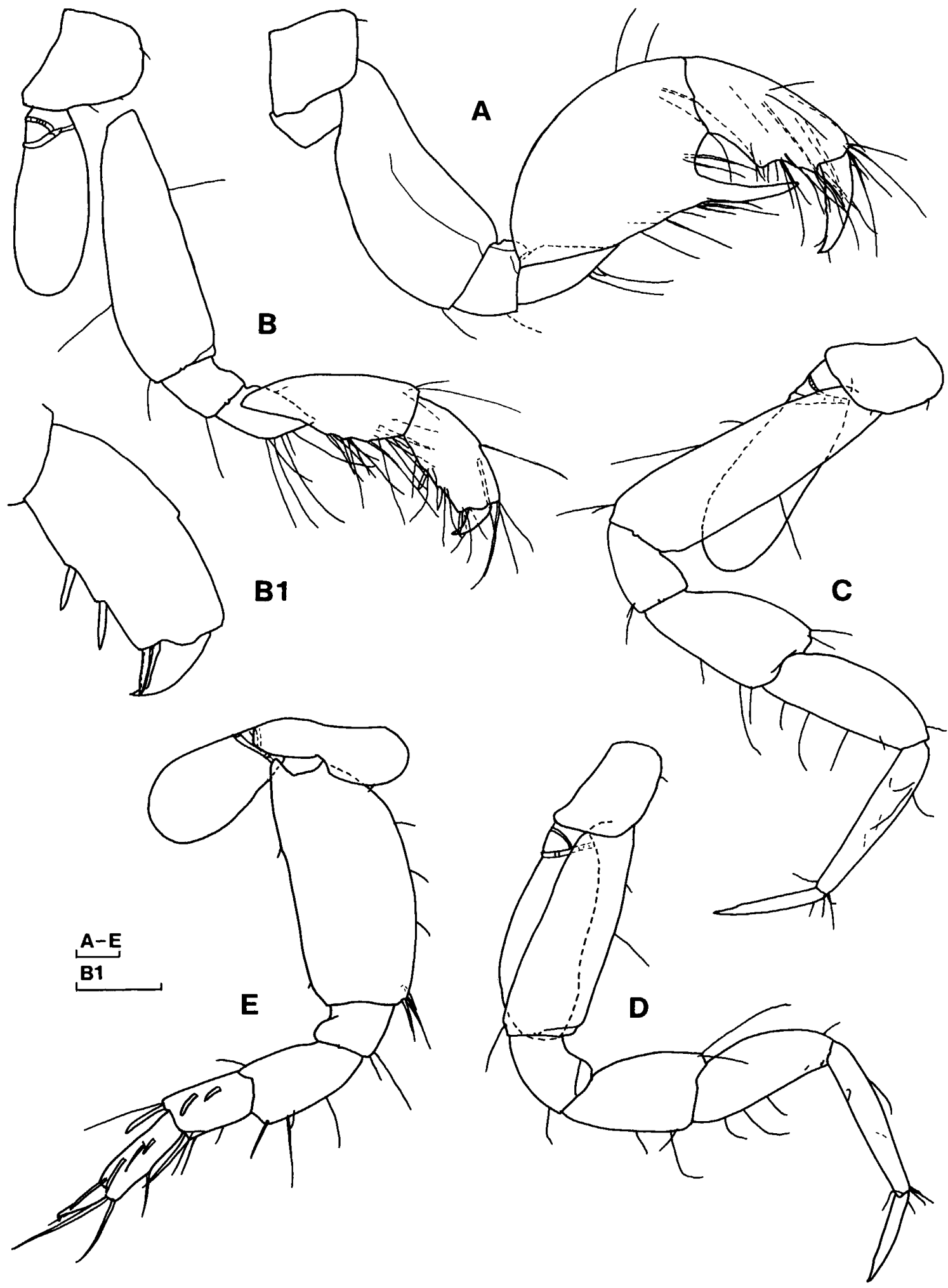

Fig. 3. Paragrandidierella minima, gen. nov., sp. nov., male (holotype, OMNH-Ar-4922). A, right gnathopod 1 (lateral view); B, right gnathopod 2 (lateral view); B1, articles 6 and 7 of right gnathopod 2 (lateral view, setae omitted); C-E, right pereopods 3-5 (lateral views). Scales: $0.05 \mathrm{~mm}$. 


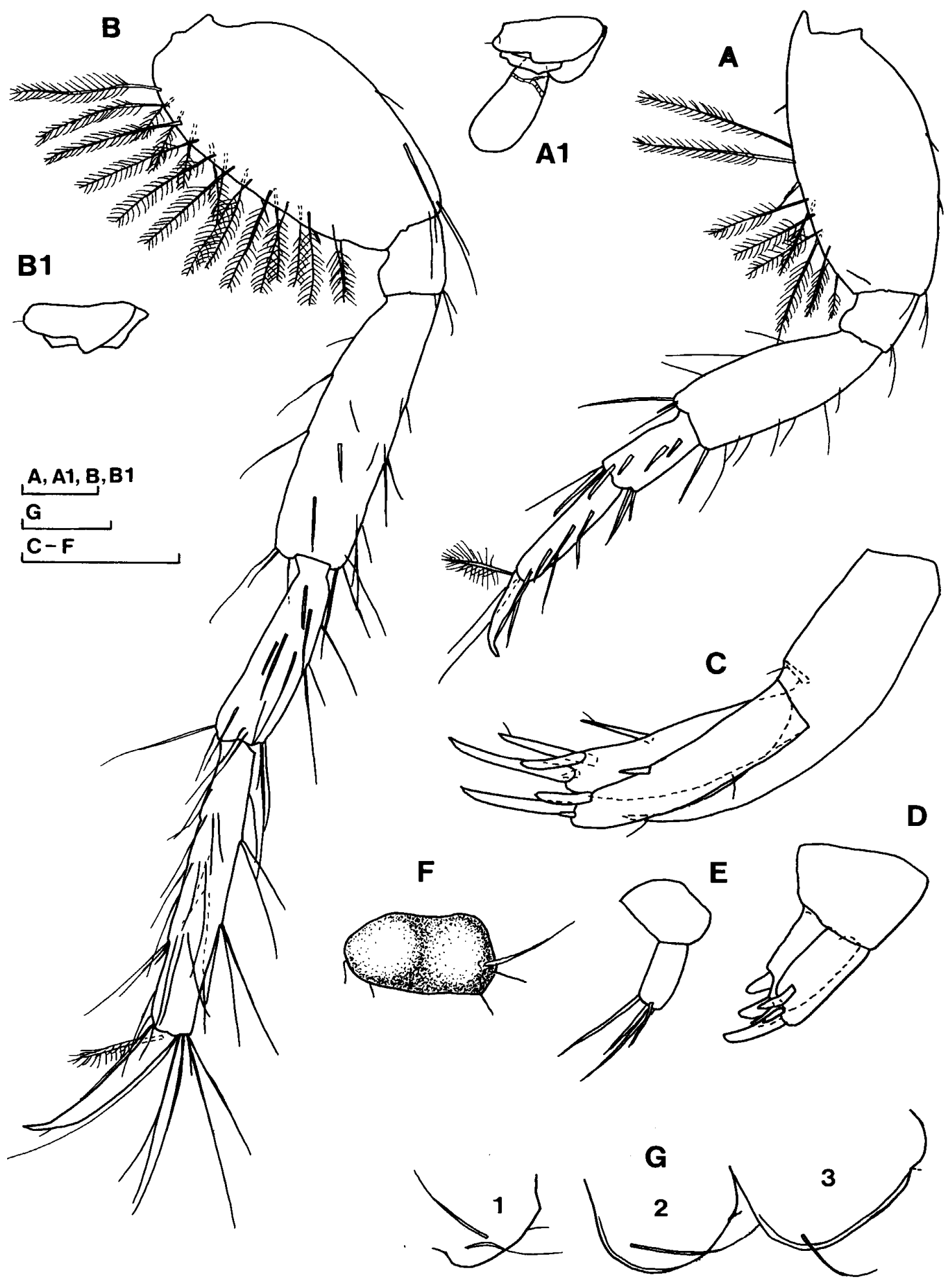

Fig. 4. Paragrandidierella minima, gen. nov., sp. nov., male (holotype, OMNH-Ar-4922). A, right pereopod 6 (lateral view); A1, right coxa 6 (lateral view); B, right pereopod 7 (lateral view); B1, right coxa 7 (lateral view); C-E, right uropods 1-3 (lateral views); F, telson (dorsal view, upper edge anterior); G, left epimeral plates 1-3 (lateral views). Scales: $0.1 \mathrm{~mm}$. 

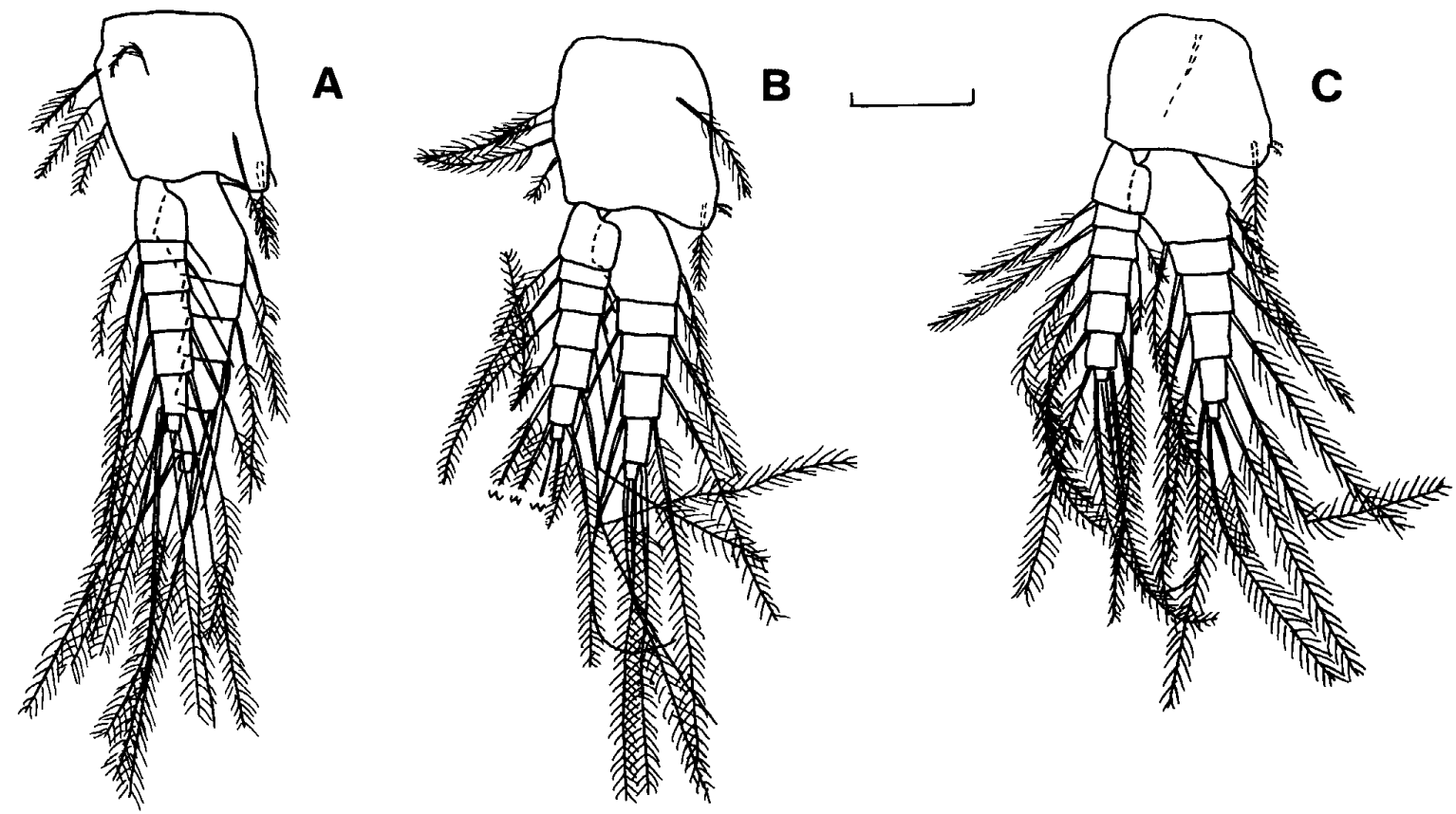

Fig. 5. Paragrandidierella minima, gen. nov., sp. nov., male (holotype, OMNH-Ar-4922). A-C, right pleopods $1-3$ (anterior views). Scale: $0.1 \mathrm{~mm}$.

longer than articles 4, broadened medianly; articles 6 narrow; articles 7 long, dirkshaped. Pereopod 5 (Fig. 3E) with narrow coxal plate; posterior half of coxal plate shallower than anterior half; article 2 rectangular, produced at posteroproximal corner, with a few short setae on posterior margin; article 4 relatively broad; article 5 with 2 lateral spines and posterodistal spine; article 6 with 3 lateral spines and posterodistal spine; article 7 short, generally straight except for slightly curved tip. Pereopod 6 (Fig. 4A) 1.5 times as long as pereopod 5; coxal plate (Fig. 4A1) small, with posterior half about two-thirds as deep as anterior half; article 2 relatively broad, with several plumose setae posteriorly, acutely produced at posteroproximal corner; article 4 with short spine and long, thick seta on posterodistal corner; article 5 with 4 lateral spines and 4 thick distal setae (3 setae on anterior corner and 1 on posterior corner); article 6 with 4 lateral spines and long distal spine, also with 3 thick setae along anterior margin; article 7 with short, plumose seta proximally. Pereopod 7 (Fig. 4B) extremely long, 1.6 times as long as pereopod 6; coxal plate (Fig. 4B1) small, with anterior part produced ventrally; article 2 ovoid, with many plumose setae posteriorly; articles 4-7 slender; article 7 with short plumose seta.

Epimeral plates 1-3 (Fig. 4G) each with 1-2 long setae on ventral margin, short seta on posteroventral corner. Pleopods (Fig. 5A-C) short; pleopod 3 shortest; peduncles each with a few plumose setae and 2 coupling spines; outer ramus shorter than inner. Uropods reduced. Uropod 1 (Fig. 4C) stout; peduncle shorter than either ramus, with spine on inner surface, and with long inter-ramal process at distal end; both rami equal in length, each with spine on dorsal surface and 3-4 spines on tip. Uropod 2 (Fig. 4D) short; peduncle shorter than wide, lacking inter-ramal process; rami as long as peduncle; tips of outer and inner rami with 4 and 2 spines, 


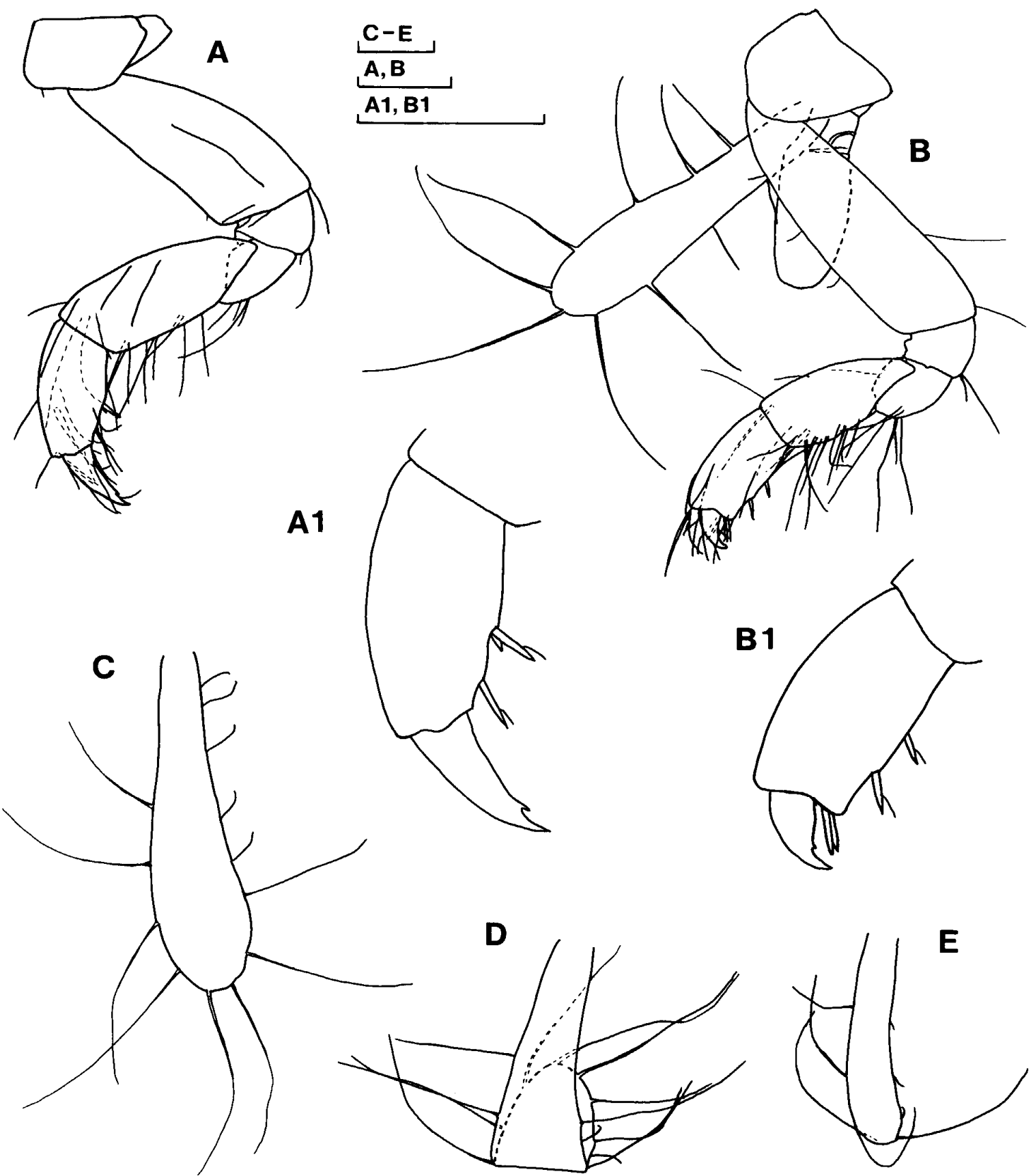

Fig. 6. Paragrandidierella minima, gen. nov., sp. nov., female (allotype, OMNH-Ar-4923). A, left gnathopod 1 (lateral view); A1, articles 6 and 7 of left gnathopod 1 (lateral view, setae omitted); B, left gnathopod 2 (lateral view); B1, articles 6 and 7 of left gnathopod 2 (lateral view, setae omitted); C-E, oostegites on left pereopods 3-5 (lateral views). Scales: $0.1 \mathrm{~mm}$.

respectively. Uropod 3 (Fig. $4 \mathrm{E}$ ) small, uniramous; peduncle subequal in length to ramus, with inner margin expanded; ramus with 4 long setae terminally. Telson (Fig. 4F) short, entire, with paired swellings on dorsal surface; lateral margins each with $2-3$ setae.

Female allotype (Fig. 6). Generally similar to male holotype except for 
gnathopods and oostegites. Gnathopod 1 (Fig. 6A) smaller than that of male, simple; coxal plate trapezoidal; article 2 broadened distally; article 3 short; article 4 roundish-triangular, with a few setae on posterior margin; article 5 long, with posterior surface setose; article 6 shorter than article 5, its posterior margin with 2 spines at midlength and subapical spine (Fig. 6A1); article 7 of medium length, with denticle on posterior margin. Gnathopod 2 (Fig. $6 \mathrm{~B}, \mathrm{~B} 1$ ) subequal in size to gnathopod 1, subchelate, similar to that of male. Oostegites (Fig. 6B-E) on pereopods $2-5$, narrow.

\section{Acknowledgement}

I would like to thank Dr. Hisashi Yokoyama of the National Research Institute of Aquaculture, who donated the material described in the present study.

\section{References}

Ariyama, H. 1996. Four species of the genus Grandidierella (Crustacea: Amphipoda: Aoridae) from Osaka Bay and the northern part of the Kii Channel, central Japan. Publications of the Seto Marine Biological Laboratory 37: 167-191.

Barnard, J. L. and Karaman, G. S. 1991. The families and genera of marine gammaridean Amphipoda (except marine gammaroids). Records of the Australian Museum, Supplement 13 (1-2): 1-866.

Myers, A. A. 1998a. New and little known Corophioidea (Amphipoda: Gammaridea) from Faroese and Icelandic waters. Journal of the Marine Biological Association of the United Kingdom 78: 211-222.

Myers, A. A. 1998b. The Amphipoda (Crustacea) of New Caledonia: Aoridae. Records of the Australian Museum 50: 187-210. 